\title{
Some glacio-micrometeorological features on the north side of Mount Qogir (K2), Karakoram mountains
}

\author{
Ding YONGJian \\ Lanzhou Institute of Glaciology and Geocryology, Chinese Academy of Sciences, Lanzhou 730000, China
}

\begin{abstract}
Measurement of wind velocity, wind direction, air temperature, precipitation and humidity were obtained at various altitudes in order to describe micrometeorological conditions on the north slope of Mount Qogir (K2). Meteorological elements were monitored above the moraine surface in the proglacial area and over the ice surface in the ablation area and snow surface in the firn area of K2 glacier. Precipitation increases quickly with altitude from the dry valley to the firn area. Relative humidity also increases with elevation. In the K2 glacier area, the highest absolute humidity occurs over the glacier tongue. The effects of melting and freezing of the surface of the glacier in the ablation area on diurnal and day-to-day changes in air temperature influence air temperature in ablation areas, decreasing diurnal range by comparison with the firn areas. On clear days, a down-valley wind blows from the firn area before sunrise and an up-valley wind after sunrise. On days with precipitation, an up-valley wind predominates in the night-time and a downvalley wind in the day-time.
\end{abstract}

\section{INTRODUCTION}

Mount Qogir (K2), the second highest mountain in the world $(8611 \mathrm{~m}$ a.s.l.), is located in the centre of the Karakoram range. Few scientists have reached it, so the region is almost a blank spot in scientific research. In 1986, Chinese and German scientists first reached the north side of Mount Qogir and measured wind, air temperature, relative humidity and precipitation at various elevations between 4130 and $5400 \mathrm{~m}$ from September to October at the end of the ablation season. This paper analyzes those meteorological data and discusses interactions between the meteorological elements and the underlying surfaces.

The K2 glacier is $21.3 \mathrm{~km}$ long with an area of $91.2 \mathrm{~km}^{2}$. The equilibrium line altitude is about $5330 \mathrm{~m}$ a.s.l. and the glacier flows from south to north to $4150 \mathrm{~m}$. Three temporary meteorological stations consisting of Lambrecht automatic weather stations and two descending points for measuring precipitation were set up during the 1986 expedition (Fig. 1, Table 1).

\section{PRECIPITATION AND WEATHER CONDITIONS}

Weather conditions differ considerably between the valley and the firn area (Fig. 2). Under normal weather conditions the sun can shine in the valley whilst snow falls in the firn area. From 11 September to 10 October 1986, clear and cloudy weather occurred for 16 and 11 days, respectively, at Station 1, and for 11 and 5 days in the firn area. Precipitation fell on day 4 at Station 1 and on day 14 between the site of P2 in the middle of the ablation area and the firn area (Table 2). Precipitation in the glacier area increases quickly with elevation. Precipitation in the firn area was $94 \mathrm{~mm}$ from 11 September to 8 October, but at the glacier terminus (Station 1) it was only $1.2 \mathrm{~mm}$. The micrometeorological difference between the dry valley and the humid firn area

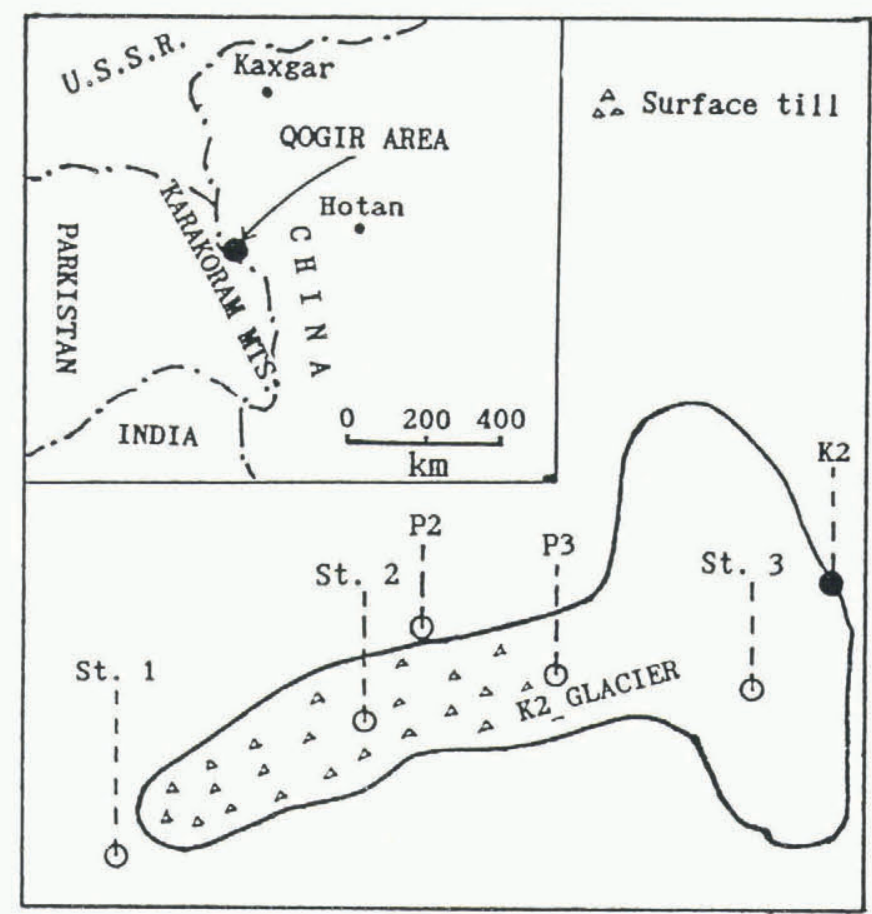

Fig. 1. Location of the study area in the Karakoram and sites of the temporary meteorological stations. For details see Table 1. 
Table 1. Description of various stations

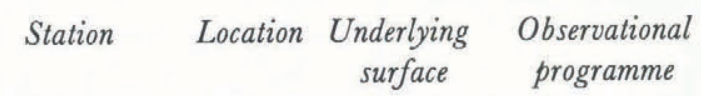

Period Altitude

\begin{tabular}{|c|c|c|c|}
\hline $\begin{array}{l}\text { Station } 1 \\
4 \text { Sept-17 Oct }\end{array}$ & valley & $\begin{array}{l}\text { moraine } \\
4130 \mathrm{~m}\end{array}$ & $\begin{array}{l}\text { wind, relative } \\
\text { humidity, radiation, } \\
\text { temperature and } \\
\text { precipitation }\end{array}$ \\
\hline Station 2 & glacier & ice & wind, relative \\
\hline $12 \mathrm{Sept}-10 \mathrm{Oct}$ & tongue & $4600 \mathrm{~m}$ & $\begin{array}{l}\text { humidity, radiation } \\
\text { and temperature }\end{array}$ \\
\hline Station 3 & firn & snow & radiation, temper- \\
\hline 22 Sept-6 Oct & area & $5400 \mathrm{~m}$ & $\begin{array}{l}\text { ature and relative } \\
\text { humidity }\end{array}$ \\
\hline $\mathrm{P} 2$ & glacier & & precipitation \\
\hline $10 \mathrm{Sept}-10 \mathrm{Oct}$ & tongue & $4760 \mathrm{~m}$ & \\
\hline P3 & firn & & precipitation \\
\hline 10 Sept-10 Oct & area & $5200 \mathrm{~m}$ & \\
\hline
\end{tabular}

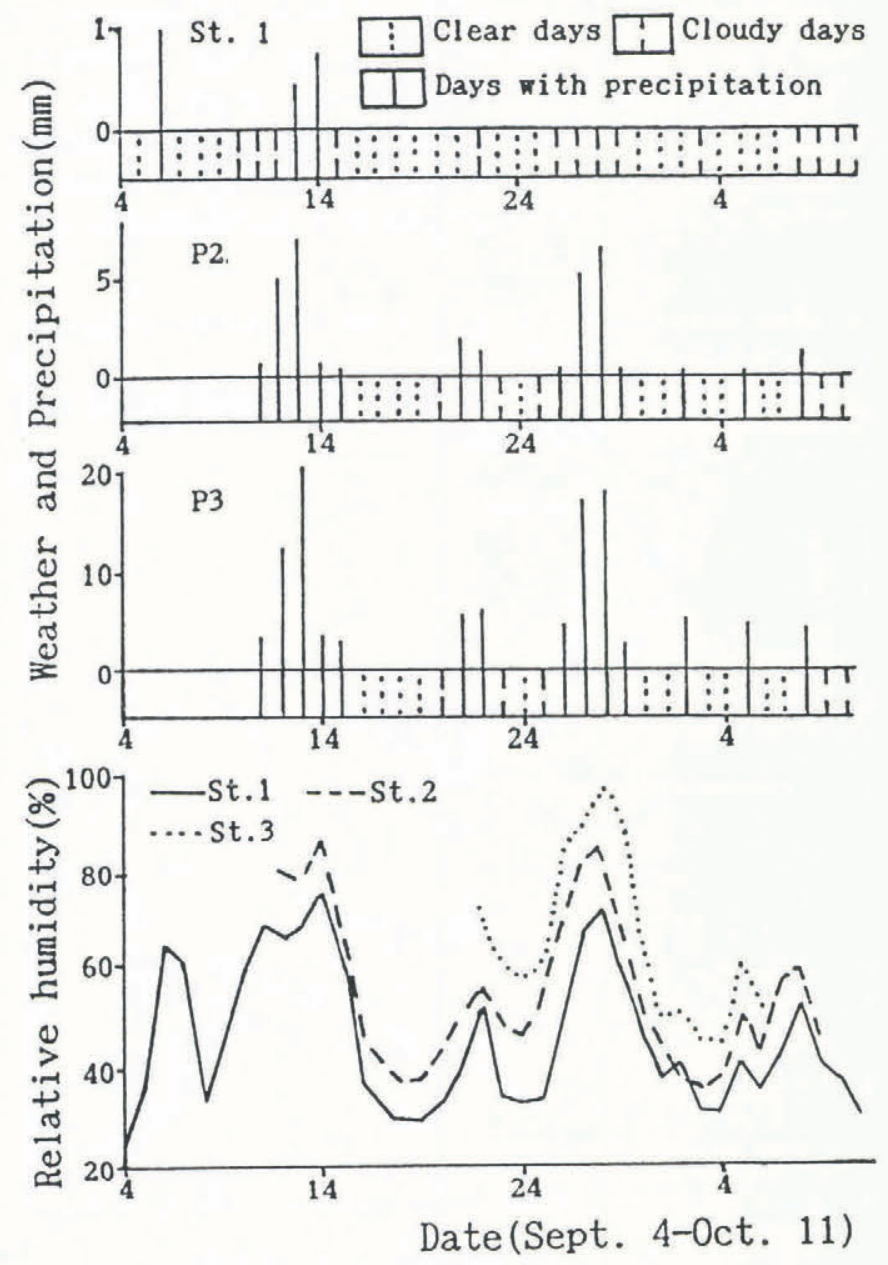

Fig. 2. Time series of precipitation, relative humidity, and weather conditions at Stations 1, 2 and 3 and P2 and P3.
Table 2. Precipitation in $\mathrm{mm}$ water equivalent in various stations

Location $\begin{aligned} & \text { Number Amount Date Remarks } \\ & \text { of events }\end{aligned}$

Station 17

2.24 Sept-17 Oct 11 Sept to 8 Oct, between 4 events, $1.2 \mathrm{~mm}$

P2 14

31.811 Sept-8 Oct

P3

94.011 Sept-8 Oct

At

108.9 13 Sept-27 Oct estimated from

$5450 \mathrm{~m}$

thickness of snow layer

is obvious, although they are only $20 \mathrm{~km}$ distant and differ by $1000 \mathrm{~m}$ in elevation. Precipitation in the high firn area is mainly affected by the humid air flow from the south side of the Karakoram, but the dry valley at the north side of $\mathrm{K} 2$ lies in the precipitation shadow of the mountains. The estimated annual accumulation at the equilibrium line altitude is more than $1000 \mathrm{~mm}$ and the annual precipitation in the valley is less than $150 \mathrm{~mm}$ (Ding, 1990).

\section{THE ANOMALY OF HUMIDITY}

Though evident differences of precipitation occur between the valley and the firn area, variations of relative humidity at Stations 1,2 and 3 are similar (see Fig. 2). Increases in relative humidity in all glacier areas are associated with precipitation in the firn area. Relative humidity between clear dry weather, through cloudy

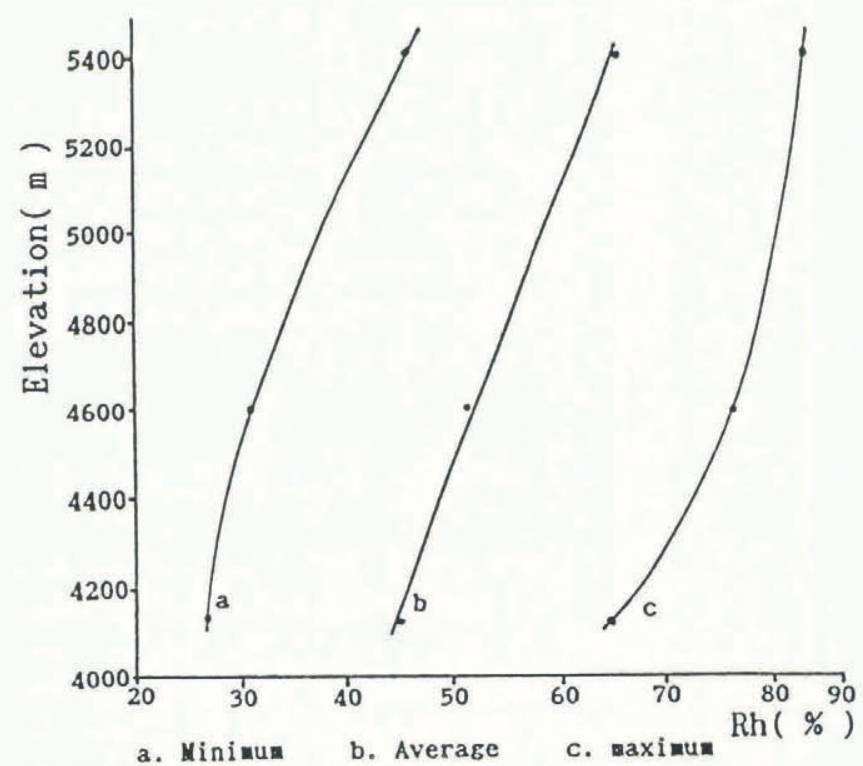

Fig. 3. Change of relative humidity with altitude (average from 22 September to 6 October). 
weather to days with precipitation tends to change from low to high (see also Fig. 4c). The vertical distribution of relative humidity is similar to that of precipitation (Fig. 3 ), in that it increases with altitude. Usually, relative humidity is highest in the firn area and lowest in the valley. Figure 3 also show that a higher gradient occurs between Stations 2 and 3 when relative humidity is low and between Stations 1 and 2 when relative humidity is high. The effect of frequent precipitation in the firn area on the relative humidity in the valley is shown. When there is low relative humidity (Fig. 3a), the difference of relative humidity between Stations 1 and 2 is small, due to the effect of dry air flow in the valley. However, when precipitation occurs in the firn area, the increase in relative humidity above the glacier tongue is faster than in the valley because of decreased precipitation toward the $\mathrm{K} 2$ valley, and a low relative humidity gradient could occur between Stations 2 and 3 (see Fig. 3c). The above results are also found in other types of weather conditions (see Fig. 4). On clear days, differences in relative humidity between Stations 1 and 2 are not obvious because up-valley northerly winds transport dry air from the valley up over the glacier surface. However, the difference in relative humidity between Stations 1 and 2 increases with a change from clear to cloudy weather when the difference of relative humidity between Stations 2 and 3 decreases. During precipitation in the firn area, the relative humidity over all glacier areas rises and differences in the daytime are reduced because downvalley winds predominate.

Statistics of relative humidity from 22 September to 6 October show that relative humidity at Station 1 at the glacier terminus was often low (between 20 and $39 \%$ ) for $40.5 \%$ of the time (Table 3 ). For Station 2 on the glacier

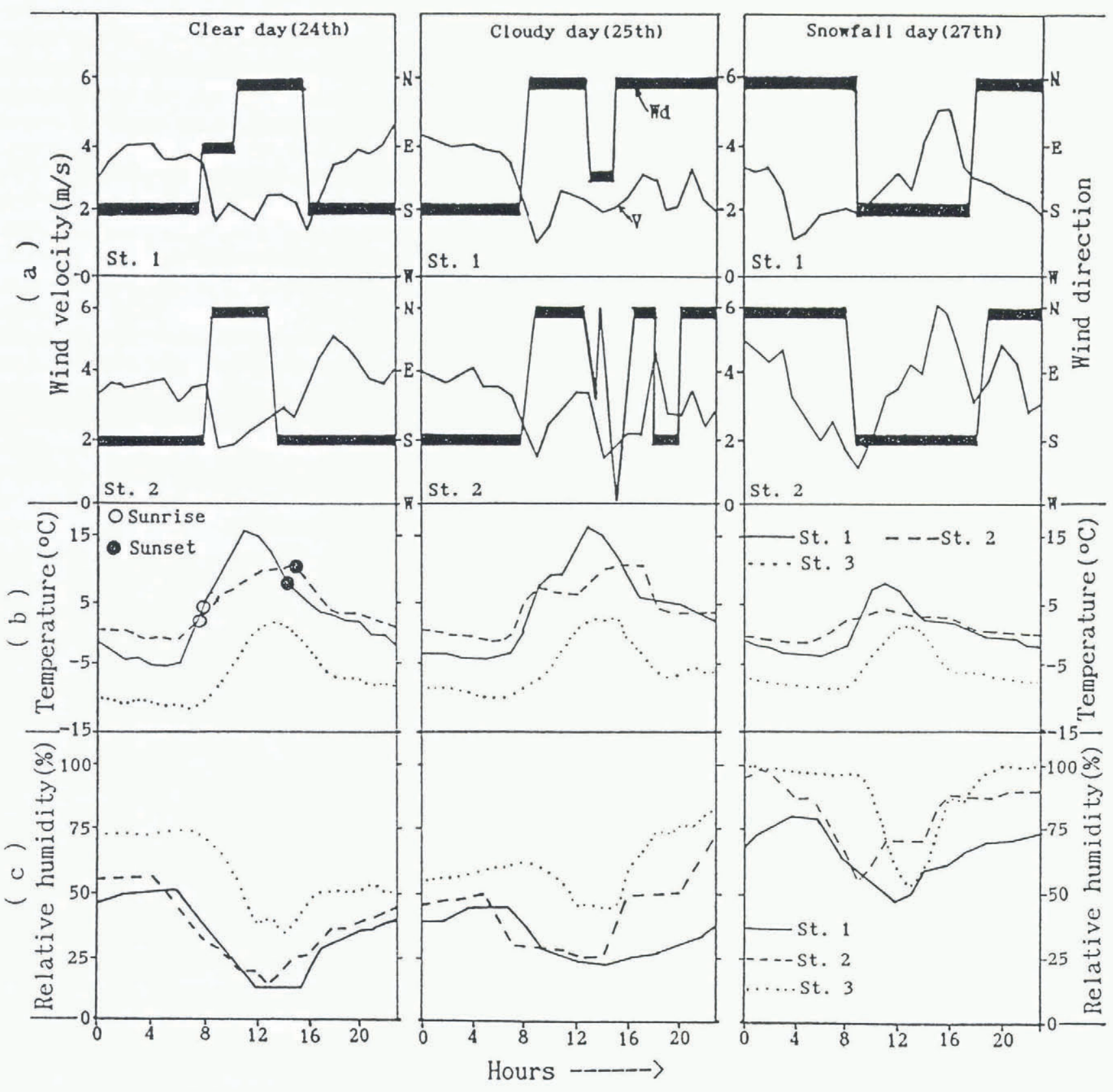

Fig. 4. Diurnal variation of wind direction $(W d)$, wind velocity $(V)$, air temperature and relative humidity in various weather types. 
Table 3. Distribution of relative humidity in a measured 360 hour period

\begin{tabular}{|c|c|c|c|c|c|c|c|c|c|c|}
\hline \multirow[b]{3}{*}{ Station } & \multicolumn{10}{|c|}{ Relative humidity \% } \\
\hline & \multicolumn{2}{|c|}{$0-19$} & \multicolumn{2}{|c|}{$20-39$} & \multicolumn{2}{|c|}{$40-59$} & \multicolumn{2}{|c|}{$60-79$} & \multicolumn{2}{|c|}{$80-100$} \\
\hline & hours & $\%$ & hours & $\%$ & hours & $\%$ & hours & $\%$ & hours & $\%$ of time \\
\hline 1 & 12.96 & 3.6 & 145.69 & 40.5 & 119.51 & 33.2 & 72.22 & 20.1 & 9.62 & 2.7 \\
\hline 2 & 10.05 & 2.8 & 101.03 & 28.1 & 132.82 & 36.9 & 60.84 & 16.9 & 55.26 & 15.3 \\
\hline 3 & 0.0 & 0.0 & 21.22 & 5.9 & 164.23 & 45.6 & 70.00 & 19.5 & 104.55 & 29.0 \\
\hline
\end{tabular}

tongue and Station 3 in the firn area, the most frequent relative humidity class was 40 to $59 \%$, but, in the firn area, relative humidity exceeded $80 \%$ for $29 \%$ of the time. Relative humidity in the firn area normally remains between 40 and $60 \%$, but exceeds $80 \%$ during precipitation. Hence, high relative humidity reflects the impact of precipitation. Another reason for high relative humidity in the firn area is the small saturation deficit caused by low air temperatures (Table 4). Table 4 also shows that the daily amplitude of absolute humidity in the glacier area is smaller than that in the valley, due to reduced evaporation on the glacier surface. Maximum absolute humidity occurs in the ablation area, decreasing both to the valley and to the accumulation zones.

\section{VARIATION IN AIR TEMPERATURE}

The effect of the underlying glacier surface on air temperature is different in different areas of the same glacier, and is especially important for a large glacier. Diurnal changes in air temperature over the various underlying surfaces are illustrated in Figure 4b. On sunny days, the surface air temperature at Station 1 reaches a maximum 3 to $4 \mathrm{~h}$ after the sunrise, i.e. at a time when solar radiation is strongest. Nevertheless, maximum air

Table 4. Averages and ranges of humidity and temperature of the air at Stations 1, 2 and 3 between 22 September and 6 October

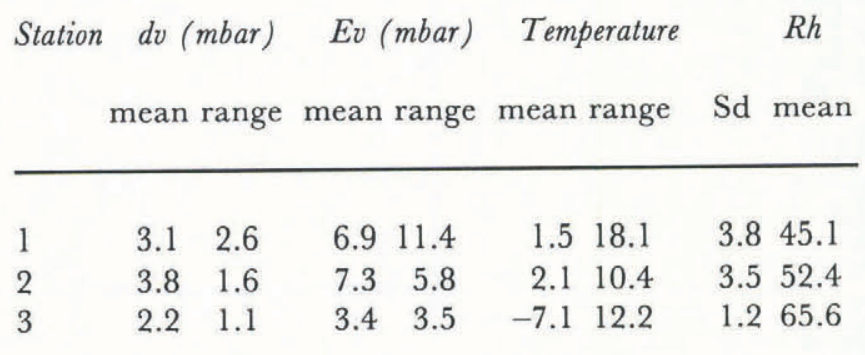

dv: absolute humidity, Ev: saturation vapour pressure, Sd: saturation deficit (ev-dv), Rh: relative humidity (\%). temperature above the ice surface is reached $6 \mathrm{~h}$ after sunrise, which is just before sunset. This time lag is a consequence of energy losses associated with ice melt. Therefore, increase in air temperature above the ice surface is slower than that above bare gound and colder snow surfaces due to the effect of the latent heat of melting. Increase in air temperature above the firn area is smaller than that over the ground after the sunrise because of the effect of the snow cover on air temperature, but it is faster than that of the ice surface.

Temperatures at Station 2 in the ablation area are anomalous. The diurnal range of temperature is the least of all three stations (see Table 4). Air temperature at night remains higher at Station 2 than at Station 1. Direct radiation is received for 1 to $3 \mathrm{~h}$ longer at Station 2, and down-valley winds may have an influence. Latent heat of melting may help reduce air temperatures by day, and latent heat of condensation may raise them by night over the ablation area.

Day-to-day changes of air temperature (Figure 5), above the ground at Station 1 and the ice surface at Station 2 are broadly parallel. It is surprising that air temperature over the ablation area was often higher than the mean daily air temperature above the ground surface

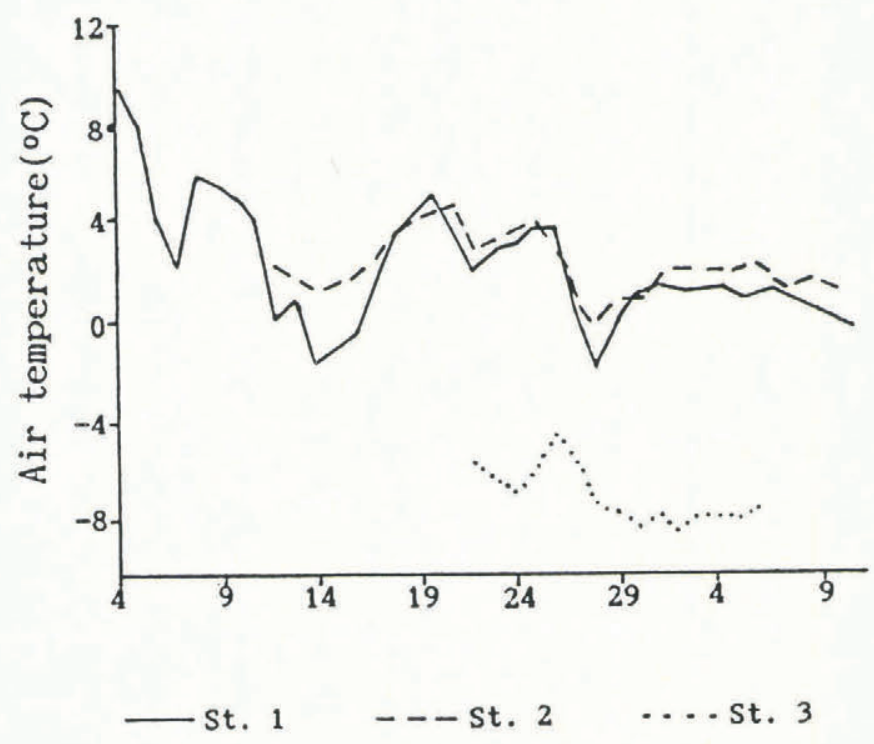

Fig. 5. Time series of air temperature at Stations 1, 2 and 3, K2 glacier valley, between 4 September and 11 October. 
at the valley station. Through time variations of air temperature at Station 1 and at Station 3 above the snow surface are poorly related. Correlation coefficients calculated between daily maximum air temperature, $T_{\max }$, and daily maximum solar radiation, $Q_{\max }$, for Stations 1,2 and 3 are $0.8,0.5$ and 0.3 , respectively, the relationship between $T_{\max }$ and $Q_{\max }$ weakening between the valley and the firn area. The relationship between temperature and radiation in the firn area is also poor.

\section{SURFACE WIND}

Figure 6 illustrates the measured frequency of wind at Stations 1 and 2. Because the K2 valley runs nearly from south to north, winds blowing downward from the firn area are southerly. Unfortunately, wind speed and direction in the firn area were not measured. Variation of wind direction at Stations 1 and 2 is broadly similar through time. In general, wind speed over the surface of the glacier tongue was slightly greater than that in the valley near the terminus. Strong down-valley winds occurred on days with clear weather and low relative humidity, and strong up-valley winds on days with precipitation and high relative humidity (Fig. 2b). This relationship between the wind and weather conditions is also apparent in Figure 4a. On clear days before the sunrise, down-glacier wind is predominant, turning to an up-valley wind during the day. On days with snowfall upvalley winds predominate in the night-time and downglacier winds in the daytime. On cloudy days wind direction is changeable. Table 5 gives the frequency of wind direction recorded by days of different weather types. It is suggested that down-valley winds predominate, except during snowfall when up-valley winds occur for a larger proportion of the day than down-valley. Upvalley winds during snowfall may be related to the approach of cold fronts from the south side of K2. As a cold front crosses the high elevation firn area, prefrontal warm air is forced to rise and orographic precipitation is produced. The up-valley winds are strengthened because
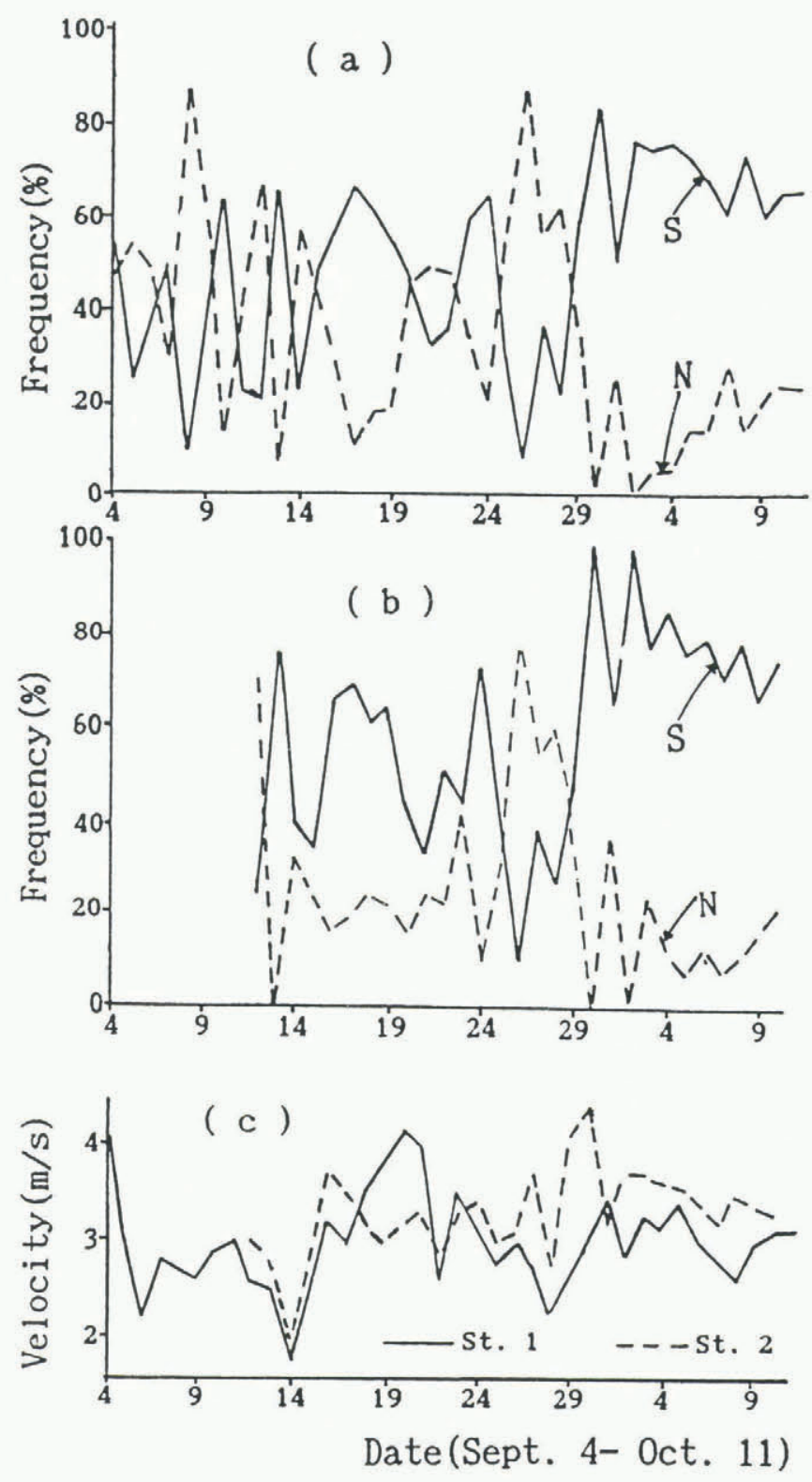

Fig. 6. Time series of the frequency of winds from north and south directions at Station 1 (a) and at Station 2(b), and wind velocity at Stations 1 and 2 (c).

Table 5. Incidence of wind direction during various weather types between 12 September and 30 October at Station 1 and Station 2

\begin{tabular}{|c|c|c|c|c|c|c|c|c|c|c|}
\hline \multirow[t]{2}{*}{$\begin{array}{l}\text { Weather type } \\
\text { in the firn area }\end{array}$} & \multicolumn{5}{|c|}{ Station 1} & \multicolumn{4}{|c|}{ Station 2} & $V$ \\
\hline & $\mathrm{T}$ & $\%$ & $\mathrm{~T}$ & $\%$ & $\mathrm{~m} / \mathrm{s}$ & $\mathrm{T}$ & $\%$ & $\mathrm{~T}$ & $\%$ & $\mathrm{~m} / \mathrm{s}$ \\
\hline Clear day & 14.64 & 61.0 & 4.61 & 19.2 & 3.3 & 16.13 & 67.2 & 4.34 & 18.1 & 3.4 \\
\hline Cloudy day & 13.39 & 55.8 & 8.35 & 34.8 & 3.4 & 13.80 & 57.5 & 5.26 & 21.9 & 3.5 \\
\hline Snowfall day & 8.62 & 35.9 & 12.34 & 51.4 & 2.7 & 9.24 & 38.5 & 10.03 & 41.8 & 3.0 \\
\hline $\begin{array}{l}\text { Period mean } \\
\text { average }\end{array}$ & 11.21 & 46.7 & 9.46 & 39.4 & 3.2 & 12.00 & 50.0 & 7.54 & 31.4 & 3.3 \\
\hline
\end{tabular}

T: duration of down-valley or up-valley wind on days of given weather type, V: mean daily wind velocity in any direction. 
of the ascent of air above the firn area. Velocity of northerly (up-valley) wind (see Fig. 4a) tends to be less than that of southerly (down-valley) winds.

The local wind system is disturbed by the influence of larger circulation systems. A prevailing west wind that begins in early October (Liu, 1980) can, for example, enhance the down-valley wind entering the valley over high passes. It can be clearly seen from Figure 6 that from the beginning of October local winds are predominantly down-valley and southerly; this includes cloudy days and days with snowfall.

\section{CONGLUSIONS}

In the valley of $\mathrm{K} 2$ glacier, precipitation and relative humidity increase with altitude, with great differences between the dry proglacial valley and the humid firn area of the glacier. Estimated annual accumulation at the ELA is more than $1000 \mathrm{~mm}$, but annual precipitation in the valley is only about $150 \mathrm{~mm}$. Maximum relative humidity occurs in the firn area but maximum absolute humidity is above the glacier tongue. Diurnal fluctuation in air temperature is smaller above the glacier tongue than in the valley below the glacier terminus. On clear days, down-valley winds occur before the sunrise and up-valley winds after. On days with precipitation, this situation is reversed. The cause of the diurnal cycle of down- and upvalley winds is not clear from these measurements.

\section{REFERENCES}

Ding Yongjian. 1990. Nourishment condition of existing glacier on the north side of the Karakoram mts. $\mathcal{F}$. Glaciol. Geocryol., 12(4), 327-334. [In Chinese with English abstract.]

Liu, G. 1980. The climate of the Batura Glacier and its adjacent areas. In Professional papers on the Batura Glacier, Karakoram mountains. Beijing, Science Press, 99-110.

The accuracy of references in the text and in this list is the responsibility of the author/s, to whom queries should be addressed. 